Article

\title{
Complementarity in Phenolic Compounds and the Antioxidant Activities of Phaseolus coccineus L. and P. vulgaris L. Landraces
}

\author{
Arelly Capistrán-Carabarin ${ }^{1}$, Elia Nora Aquino-Bolaños ${ }^{1}$, Yatzil Denih García-Díaz ${ }^{2}$,

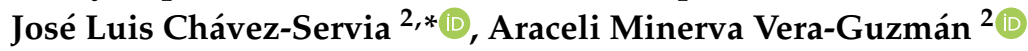 \\ and José Cruz Carrillo-Rodríguez ${ }^{3}$ \\ 1 Instituto de Ciencias Básicas, Universidad Veracruzana, Xalapa, Veracruz 91194, Mexico \\ 2 CIIDIR-Oaxaca, Instituto Politécnico Nacional, Santa Cruz Xoxocotlán, Oaxaca 71230, Mexico \\ 3 Instituto Tecnológico del Valle de Oaxaca, Santa Cruz Xoxocotlán, Oaxaca 71230, Mexico \\ * Correspondence: jchavezs@ipn.mx; Tel.: +52-951-517-0610
}

Received: 17 June 2019; Accepted: 25 July 2019; Published: 28 July 2019

\begin{abstract}
Phaseolus vulgaris L. is one of the most consumed and documented legumes in regard to its grain composition, but little is known about $P$. coccineus $\mathrm{L}$. To evaluate and compare the phenolic compound content and antioxidant activity between landraces of $P$. coccineus and $P$. vulgaris, a total of 14 accessions of P. coccineus and P. vulgaris were collected from farmers in Oaxaca, Mexico. Based on reference standards and spectrophotometry, the polyphenol, flavonoid and anthocyanin contents were quantified, and the antioxidant activity was determined by the 2,2-diphenyl-1-picrylhydrazyl (DPPH) method. The results showed significant differences $(p \leq 0.05)$ between species and accessions, where P. coccineus and P. vulgaris significantly differed in their contents of polyphenols, flavonoids, and anthocyanins, as well as their antioxidant activity in the seed coat and cotyledons. Higher concentrations were found in the seed coat than in the cotyledons for both species. P. vulgaris had a higher anthocyanin content in the seed coat and a higher flavonoid content in the cotyledons than $P$. coccineus, but it did not for the other compounds tested. There was high variability among the accessions that were classified into four phenotypic groups: Two of $P$. coccineus, one of a $P$. coccineus-vulgaris mixed group, and one group of $P$. vulgaris.
\end{abstract}

Keywords: scarlet runner bean; spectrophotometry; bioactive compounds; landraces; indigenous communities

\section{Introduction}

The genus Phaseolus (Fabaceae) includes more than 400 species, five of which are the best known, including-in order of commercial importance-Phaseolus vulgaris L., Phaseolus coccineus L., Phaseolus lunatus L., Phaseolus acutifolius A. Gray., and Phaseolus dumosus Macfady. All have their origin, domestication and diversification in America. The first three have a worldwide distribution [1-3]. In Mexico and Central America, the greatest diversity of P. vulgaris and P. coccineus are conserved in situ as part of the traditional cultivation systems, backyards and forests [2]. These regions have the greatest diversity of indigenous groups and ethnolinguistic variants $[4,5]$.

$P$. vulgaris is one of the most documented species of the genus Phaseolus in regard to grain composition, including its polyphenol profile [6]; phenols, flavonoids, and carotenes content, as well as their antioxidant activity [7-9]; and antinutritional agents, such as trypsin, tannins and lectins [10]. In the case of P. coccineus, the concentration of phenolic acids [11], proximal analysis and mineral content have been determined [12,13]. In specific cases, it was observed that the content and composition of $P$. vulgaris grains differ from those of $P$. coccineus. For example, cyanidin-3-glucoside, 
delphinidin-3-glucoside, cyanidin, methyldelphinidin, and methylcyanidin anthocyanins are more common in P. coccineus, among others, whereas peonidin, petunidin and malvidin are more common in $P$. vulgaris $[14,15]$. This commonality indicates significant differences in grain composition according to the species and genotype.

Wild and cultivated P. coccineus are distributed from Mexico to Central America. In Oaxaca, Mexico, both germplasm sources grow simultaneously in adjacent areas; the wild populations grow in natural vegetation zones, fences or back yards near cropping parcels, and farmers commonly move seed from wild populations to cultivated plots, promoting a continual gene flow [16]. Therefore, $P$. coccineus variants preserved on-farm have hybrid combinations of morphological and biochemical traits of seed between wild and cultivated forms. In the evaluation conducted by Quiroz-Sodi et al. [11], they analyzed three cultivated varieties from Queretaro, $650 \mathrm{~km}$ away from Oaxaca, but not hybrid combinations or wild forms of $P$. coccineus. Additionally, in the southern region of Mexico, which includes Oaxaca, farmers preserve in situ hundreds of landraces known regionally but not yet evaluated in terms of bioactive compounds, which are broadly used as food by rural communities. In such a communitarian context, it is relevant to evaluate the contribution of $P$. coccineus to the diet in terms of its beneficial potential for health and to compare their composition with P. vulgaris throughout the evaluation of secondary metabolites in the cotyledons and seed coat.

Hundreds of $P$. coccineus and $P$. vulgaris landraces are cultivated traditionally in the central-south of Mexico and Central America under environmental conditions restrictive of soil fertility, without the use of agrochemical supplies under rain-fed conditions, and just for the use for self-consumption at the household level; all of these agroecological factors influence grain composition as well as genotype or variant cultivated $[17,18]$. In addition, in the rural communities from this regions, $65 \%$ or more of the population lives in poverty, with a high degree of marginalization, food insecurity, malnutrition associated with excess weight and obesity, and social inequity [19], but they have an annual per capita consumption of beans ranging from 9.8 to $25.9 \mathrm{~kg}$, which implies a high contribution to the communitarian diet [20]. Thus, it is necessary to evaluate the nutritional-nutraceutical contribution between P. coccineus and P. vulgaris and to obtain estimators of the phenotypic variation inter- and intraspecific in terms of phenolic compounds and antioxidant activity to propose strategies of direct use of such landraces or to start a plant breeding program.

The bioactive compounds identified in the common bean are associated with biological activity in reducing the risk of obesity, diabetes, ischemic cardiomyopathy, cardiovascular diseases, some types of cancer, Alzheimer's disease, Parkinson's disease, stress, anxiety, depression, and digestive tract diseases, among others [6,21-26]. A similar potential effect can also be attributed to P. coccineus, even though it is poorly documented [27]. In particular, the indigenous communities of Mexico and Central America, consume the flowers, green beans (fresh pod) and young shoots of P. coccineus, in addition to the grain [28]. In this context, the phenolic compound content and antioxidant activity were tested and compared between landraces of P. coccineus and P. vulgaris cultivated by indigenous communities of Oaxaca, Mexico.

\section{Materials and Methods}

\subsection{Germplasm Evaluated}

Fourteen native bean populations were evaluated; eight Phaseolus coccineus L. (scarlet runner bean) and six P. vulgaris (common bean) accessions were collected in different indigenous communities of Oaxaca (13) and Veracruz (1), Mexico (Table 1). After collection, a biophysical description of the seed lot of each accession was made. 
Table 1. Accessions of Phaseolus coccineus and Phaseolus vulgaris landraces evaluated.

\begin{tabular}{|c|c|c|c|}
\hline ID-Accession & $\begin{array}{c}\text { Community of Origin } \\
\text { (North Latitude; West Longitude; } \\
\text { Altitude in Masl }{ }^{1} \text { ) }\end{array}$ & Bean Color & $\begin{array}{l}\text { Pictures of Grain } \\
\text { Characteristic }\end{array}$ \\
\hline \multicolumn{4}{|c|}{ Phaseolus coccineus } \\
\hline Gordo & $\begin{array}{c}\text { Coatepec, Veracruz } \\
\left(19^{\circ} 27^{\prime} 19^{\prime \prime} ; 96^{\circ} 57^{\prime} 31^{\prime \prime} ; 1192\right)\end{array}$ & Light brown & \\
\hline SMT & $\begin{array}{l}\text { San Miguel Tlanichico, Zaachila, } \\
\text { Oaxaca }\left(16^{\circ} 55^{\prime} ; 96^{\circ} 48^{\prime} ; 1520\right)\end{array}$ & Gray-black & \\
\hline SL-01 & $\begin{array}{l}\text { Santa Lucía Miahuatlán, Oaxaca } \\
\qquad\left(16^{\circ} 11^{\prime} ; 96^{\circ} 37^{\prime} ; 2000\right)\end{array}$ & Black & \\
\hline SL-02 & $\begin{array}{l}\text { Santa Lucía Miahuatlán, Oaxaca } \\
\qquad\left(16^{\circ} 11^{\prime} ; 96^{\circ} 37^{\prime} ; 2000\right)\end{array}$ & Brown-red & \\
\hline Z-01 & $\begin{array}{l}\text { Villa de Zaachila, Oaxaca } \\
\left(16^{\circ} 56^{\prime} ; 96^{\circ} 45^{\prime} ; 1520\right)\end{array}$ & Red-purple & \\
\hline Z-02 & $\begin{array}{l}\text { Villa de Zaachila, Oaxaca } \\
\left(16^{\circ} 56^{\prime} ; 96^{\circ} 45^{\prime} ; 1520\right)\end{array}$ & Gray-black & \\
\hline Z-03 & $\begin{array}{l}\text { Villa de Zaachila, Oaxaca } \\
\left(16^{\circ} 56^{\prime} ; 96^{\circ} 45^{\prime} ; 1520\right)\end{array}$ & Gray-black & \\
\hline Z-04 & $\begin{array}{l}\text { Villa de Zaachila, Oaxaca } \\
\left(16^{\circ} 56^{\prime} ; 96^{\circ} 45^{\prime} ; 1520\right)\end{array}$ & Gray-black & \\
\hline \multicolumn{4}{|c|}{ Phaseolus vulgaris } \\
\hline Bart & $\begin{array}{l}\text { San Bartolomé Quialana, Oaxaca } \\
\qquad\left(16^{\circ} 54^{\prime} ; 96^{\circ} 30 ; 1780\right)\end{array}$ & Black & \\
\hline SDA & $\begin{array}{l}\text { Santo Domingo Amatlan, Oaxaca } \\
\qquad\left(16^{\circ} 18^{\prime} ; 96^{\circ} 26^{\prime} ; 1540\right)\end{array}$ & Black & \\
\hline SIA & $\begin{array}{l}\text { San Idelfonso Amatlán, Oaxaca } \\
\qquad\left(16^{\circ} 20^{\prime} ; 96^{\circ} 29^{\prime} ; 1540\right)\end{array}$ & Black & \\
\hline SJP & $\begin{array}{l}\text { San José del Peñasco, Oaxaca } \\
\qquad\left(16^{\circ} 18^{\prime} ; 96^{\circ} 30^{\prime} ; 1589\right)\end{array}$ & Black & \\
\hline SS-01 & $\begin{array}{l}\text { San Sebastián Abasolo, Oaxaca } \\
\qquad\left(17^{\circ} 00^{\prime} ; 96^{\circ} 35^{\prime} ; 1550\right)\end{array}$ & Black & \\
\hline SS-02 & $\begin{array}{l}\text { San Sebastián Abasolo, Oaxaca } \\
\qquad\left(17^{\circ} 00^{\prime} ; 96^{\circ} 35^{\prime} ; 1550\right)\end{array}$ & Black & \\
\hline
\end{tabular}

\footnotetext{
${ }^{1}$ masl $=$ Meters above sea level.
} 


\subsection{Sample Preparation}

A sample of $100 \mathrm{~g}$ of seeds from each accession was left to soak in distilled water for $12 \mathrm{~h}$ at $25{ }^{\circ} \mathrm{C}$, followed by the manual separation of the seed coat from the cotyledons; after this separation, they were handled separately. Subsequently, a $3 \mathrm{~g}$ sample of seed coat and another similar portion of cotyledons were homogenized (DAIHAN-brand HG-15-A Gonju-Si, Gangwon, Republic of Korea) with $25 \mathrm{~mL}$ of $70 \%$ acidified acetone (acetone:water:acetic acid, 70:29.5:0.5, $v / v / v$ ) according to the method described by Aquino-Bolaños et al. [29]. Each extract was centrifuged at $4000 \mathrm{rpm}$ for $20 \mathrm{~min}$ at $10^{\circ} \mathrm{C}$ (Hettich centrifuge, Universal 32R, Tuttlingen, Germany), and the supernatant was recovered. Again, the process was repeated a second time under the same conditions, and, finally, both supernatants were mixed for use in the analyses.

\subsection{Evaluation of Polyphenols, Flavonoids, Anthocyanins, and Antioxidant Activity}

Total polyphenols. They were determined by the method described by Singleton and Rossi [30], and the reaction absorbance was measured at $750 \mathrm{~nm}$ in a UV-visible spectrophotometer (Jenway 6305, Bibby Scientific Ltd., Dunmow, Essex, UK). The quantification was performed based on a standard curve of gallic acid $\left(0.020\right.$ to $\left.0.165 \mathrm{mg} \mathrm{mL}^{-1}\right)$, and the results were expressed in mg equivalents of gallic acid per gram of dry sample (mg GAE g $\left.{ }^{-1} \mathrm{dw}\right)$.

Total flavonoids. The spectrophotometric evaluation of the total flavonoids was based on the method reported by Zhishen et al. [31]. The absorbance of total flavonoids was measured at $510 \mathrm{~nm}$, and quantification was performed based on a standard curve of (+)catechin $\left(0.012\right.$ to $\left.0.121 \mathrm{mg} \mathrm{mL}^{-1}\right)$. The values were expressed in mg equivalents of catechin per gram of dry sample ( $\mathrm{mg} \mathrm{CE} \mathrm{g}^{-1} \mathrm{dw}$ ).

Monomeric anthocyanins. The anthocyanin content was determined by the differential $\mathrm{pH}$ method described by Giusti and Wrolstad [32]. Two dilutions of the extract were made, one with potassium chloride buffer at $\mathrm{pH} 1.0$ and the second with sodium acetate buffer at $\mathrm{pH} 4.5$, diluting each by the previously determined dilution factor. Subsequently, a spectrophotometer was used to generate an absorption spectrum in the range of $460-710 \mathrm{~nm}$ to determine the maximum absorbance. The concentration of monomeric anthocyanins (MA) was calculated according to the following equation: $\mathrm{AM}=\left(\mathrm{A}^{*} \mathrm{PM}^{*} \mathrm{FD}^{*} 1000\right) /\left(\varepsilon^{*} \mathrm{I}\right)$, where the absorbance of sample A corresponds to $(\mathrm{A} \lambda 510-\mathrm{A} \lambda 700) \mathrm{pH} 1.0$ $-(\mathrm{A} \lambda 510-\mathrm{A} \lambda 700) \mathrm{pH} 4.5 ; \mathrm{MW}=449.2$ is the molecular weight of cyanidin-3-glucoside; $\varepsilon=26,900 \mathrm{~g} / \mathrm{mol}$ is the molar absorptivity of the cyanidin-3-glucoside; FD is the dilution factor used; and I is the cell length $(1 \mathrm{~cm})$. The results were expressed as $\mathrm{mg}$ of cyanidin-3-glucoside per gram of dry sample $\left(\mathrm{mg} \mathrm{C} 3 \mathrm{G} \mathrm{g}^{-1} \mathrm{dw}\right)$.

Antioxidant activity. The antioxidant activity was evaluated by the 2,2-diphenyl-1-picrylhydrazyl (DPPH) method reported by Brand-Williams et al. [33]. A $100 \mu \mathrm{L}$ sample of the extract was reacted with $2.9 \mathrm{~mL}$ of DPPH reagent and allowed to stand for $30 \mathrm{~min}$ at room temperature. The absorbance was measured using a UV-vis spectrophotometer (Shimadzu UV-1800, Kyoto, Japan) at $517 \mathrm{~nm}$ using $80 \%(v / v)$ methanol as the target. To quantify the antioxidant activity, it was performed based on the inhibition percentage of a standard 6-hydroxy-2,5,7,8-tetramethylchroman-2-carboxylic acid (Trolox) curve in a concentration range of $0.13-0.79 \mu \mathrm{mol}$ equivalents of Trolox per mL. The results were expressed in micromoles of Trolox equivalents per gram of dry sample ( $\mu \mathrm{mol} \mathrm{Eq.} \mathrm{Trolox} \mathrm{g}^{-1} \mathrm{dw}$ ).

\subsection{Statistical Analysis}

A database with all results was integrated, and an analysis of variance was performed using a completely random design with the nesting of accessions within species. Comparisons among species and accessions were made by the Tukey method ( $p \leq 0.05)$. Subsequently, a cluster analysis of hierarchical clustering was performed based on the averages of each variable by accession using the Ward method. Once the groups were defined, a canonical discriminant analysis was performed to test the variability and dispersion of accessions as a function of the phenolic compound content and antioxidant activity. All statistical analyses were performed using SAS software [34]. 


\section{Results}

According to the description of the seeds by accession, $P$. coccineus presented a variation of 16.2-18.2 $\mathrm{mm}$ in length, 9.3-12.9 $\mathrm{mm}$ in width, 6.4-8.5 $\mathrm{mm}$ in thickness, $14.2-92.0 \mathrm{~g}$ in weight, and 62.5-183.5 mL in volume for 100 grains. In the case of $P$. vulgaris, the length, width and thickness of seeds varied from 9.1 to 10.2 , from 5.3 to 5.7 and from 3.9 to $4.3 \mathrm{~mm}$, respectively. The weight and volume of 100 grains of P. vulgaris ranged from 12.9 to $14.8 \mathrm{~g}$ and from 61 to $62.5 \mathrm{~mL}$, respectively. The descriptive statistics showed the substantial differences in the larger dimensions, volume and weight of $P$. coccineus seeds compared to $P$. vulgaris, although the concentration of compounds may have another pattern of variation.

In the analysis of variance, significant differences were determined among species and accessions within species for the polyphenol, flavonoid, and anthocyanin contents, as well as the antioxidant activity by DPPH. Likewise, as a function of the magnitude of the mean squares value, it was estimated that the variance due to species source is greater than the variance among accessions of the same species (Table 2). This indicates that the variation between species is greater than that within each species and reflects part of the evolutionary differences between P. coccineus and P. vulgaris $[35,36]$.

Table 2. Significance of square means of the analysis of variance from phenolic compounds and antioxidant activity of $P$. coccineus and P. vulgaris grains.

\begin{tabular}{|c|c|c|c|c|c|c|c|}
\hline \multirow{2}{*}{ Sources of Variation } & \multicolumn{4}{|c|}{ Seed Coat } & \multicolumn{3}{|c|}{ Cotyledons } \\
\hline & $\begin{array}{c}\text { Total } \\
\text { Polyphenols }\end{array}$ & Flavon. & Anthocyan. & $\begin{array}{c}\text { Antioxidant } \\
\text { Activity }\end{array}$ & $\begin{array}{c}\text { Total } \\
\text { Polyphenols }\end{array}$ & Flavon. & $\begin{array}{c}\text { Antioxidant } \\
\text { Activity }\end{array}$ \\
\hline Species & $\begin{array}{c}31853.3^{* *} \\
(84.1)^{2}\end{array}$ & $\begin{array}{c}236.6^{* *} \\
(65.8)\end{array}$ & $\begin{array}{c}467.3^{* *} \\
(98.3)\end{array}$ & $\begin{array}{c}1563069^{* *} \\
(85.4)\end{array}$ & $\begin{array}{c}0.599 * * \\
(79.7)\end{array}$ & $\begin{array}{c}0.040 * * \\
(64.5)\end{array}$ & $\begin{array}{c}40.43^{* *} \\
(77.9)\end{array}$ \\
\hline Accessions (species) ${ }^{1}$ & $\begin{array}{c}5999.7^{* *} \\
(15.8)\end{array}$ & $\begin{array}{c}122.8 \text { ** } \\
(34.2)\end{array}$ & $\begin{array}{l}8.1 \text { ** } \\
(1.7)\end{array}$ & $\begin{array}{c}267007^{* *} \\
(14.6)\end{array}$ & $\begin{array}{c}0.152 * * \\
(20.2)\end{array}$ & $\begin{array}{c}0.021 \text { ** } \\
(33.9)\end{array}$ & $\begin{array}{c}11.43^{* *} \\
(22.0)\end{array}$ \\
\hline Error & $\begin{array}{c}1.94 \\
(<0.01)\end{array}$ & $\begin{array}{c}0.05 \\
(<0.01)\end{array}$ & $\begin{array}{c}0.19 \\
(<0.01)\end{array}$ & $\begin{array}{c}261.6 \\
(<0.01)\end{array}$ & $\begin{array}{c}<0.001 \\
(0.1)\end{array}$ & $\begin{array}{c}<0.001 \\
(1.6)\end{array}$ & $\begin{array}{l}0.07 \\
(0.1)\end{array}$ \\
\hline Coef. of variation (\%) & 1.1 & 1.5 & 13.6 & 1.4 & 1.2 & 6.6 & 2.9 \\
\hline
\end{tabular}

Flavon. = Flavonoids; Anthocyan. = Monomeric anthocyanins; ${ }^{* *}$ significant at $p<0.01{ }^{1}$ indicates accessions nested in species; ${ }^{2}$ values in parentheses are percentage variance components.

The average composition and antioxidant activity in the seed coat and cotyledons of P. coccineus were significantly different from those of P. vulgaris, such as in regard to the polyphenols, flavonoids and antioxidant activity (by DPPH) of the seed coat, and the polyphenols and antioxidant activity of the cotyledons were higher in P. coccineus than those in P. vulgaris. However, in regard to the monomeric anthocyanin content in the seed coat and flavonoids in the cotyledons, the concentrations were greater in P. vulgaris than those in P. coccineus (Table 3). In this case, the monomeric anthocyanin content in $P$. vulgaris was nine times higher than in $P$. coccineus, although the latter has a larger seed size and consequently a greater amount of tissue in the seed coat. Additionally, the results show that polyphenol contents, the flavonoid contents, and the antioxidant activity in the seed coat are significantly higher than those in the cotyledons, and, for this reason, the seed coat is now of greater interest as a food supplement and for the processed food industry.

The variation evaluated of phenolic compounds and antioxidant activity within $P$. coccineus and P. vulgaris showed different patterns among species. For example, for anthocyanin contents, $P$. coccineus

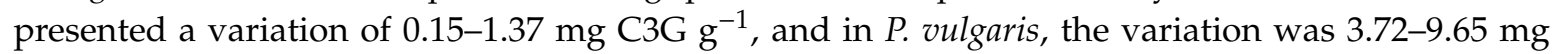
$\mathrm{C} 3 \mathrm{G} \mathrm{g}^{-1}$ in the seed coat. Therefore, depending on the accessions evaluated, the results indicate an intraspecific differentiation in the seed coat anthocyanins within each species. For the polyphenol contents of the seed coat and cotyledons, P. coccineus accessions with higher phenol contents in the seed coat also showed high values in the cotyledons, and a similar trend was observed for P. vulgaris accessions with a lower phenol content in the seed coat, as they also had a lower content in the cotyledons (Table 3). 
Table 3. Comparison of means among accessions and between species of P. coccineus and P. vulgaris in relation to the phenols, flavonoids, anthocyanins and antioxidant activity.

\begin{tabular}{|c|c|c|c|c|c|c|c|}
\hline \multirow{2}{*}{ ID-Accession } & \multicolumn{4}{|c|}{ Seed Coat } & \multicolumn{3}{|c|}{ Cotyledons } \\
\hline & $\begin{array}{c}\text { Total } \\
\text { Polyphenols }^{1}\end{array}$ & Flavon. $^{2}$ & Anthocy. ${ }^{3}$ & $\begin{array}{c}\text { Antiox. } \\
\text { Activity } \\
\end{array}$ & $\begin{array}{c}\text { Total } \\
\text { Polyphenols }{ }^{1}\end{array}$ & Flavon. $^{2}$ & $\begin{array}{c}\text { Antiox. } \\
\text { Activity }\end{array}$ \\
\hline \multicolumn{8}{|c|}{ P. coccineus $(\mathrm{Pc})$} \\
\hline Gordo & $152.4 \mathrm{~d}^{5}$ & $22.0 \mathrm{c}$ & $0.15 \mathrm{~g}$ & $1169.4 \mathrm{~d}$ & $2.41 \mathrm{~b}$ & $0.30 \mathrm{~d}$ & $8.11 \mathrm{f}$ \\
\hline SMT & $218.0 \mathrm{a}$ & $26.3 \mathrm{a}$ & $0.40 \mathrm{fg}$ & $1789.2 \mathrm{a}$ & $2.49 \mathrm{a}$ & $0.40 \mathrm{~b}$ & $11.28 \mathrm{~b}$ \\
\hline SL-01 & $78.3 \mathrm{j}$ & $12.7 \mathrm{fg}$ & $1.12 \mathrm{fg}$ & 888.1 ef & $2.18 \mathrm{e}$ & $0.30 \mathrm{~d}$ & 8.40 ef \\
\hline SL-02 & $95.5 \mathrm{i}$ & $12.1 \mathrm{~h}$ & $0.30 \mathrm{fg}$ & $813.2 \mathrm{~g}$ & $2.28 \mathrm{~d}$ & $0.40 \mathrm{~b}$ & $7.18 \mathrm{~g}$ \\
\hline Z-01 & $126.5 \mathrm{f}$ & $22.7 \mathrm{~b}$ & $0.52 \mathrm{fg}$ & $1261.0 \mathrm{c}$ & $2.16 \mathrm{e}$ & $0.32 \mathrm{~cd}$ & $9.08 \mathrm{~d}$ \\
\hline $\mathrm{Z}-02$ & $136.6 \mathrm{e}$ & $6.3 \mathrm{k}$ & $1.37 \mathrm{f}$ & $1297.4 \mathrm{c}$ & $2.08 \mathrm{f}$ & $0.20 \mathrm{e}$ & $9.96 \mathrm{c}$ \\
\hline $\mathrm{Z}-03$ & $194.9 \mathrm{~b}$ & $9.8 \mathrm{j}$ & $0.75 \mathrm{fg}$ & $1536.4 \mathrm{~b}$ & $2.52 \mathrm{a}$ & $0.27 \mathrm{~d}$ & $13.52 \mathrm{a}$ \\
\hline Z-04 & $188.8 \mathrm{c}$ & $20.2 \mathrm{~d}$ & $0.67 \mathrm{fg}$ & $1498.0 \mathrm{~b}$ & $2.37 \mathrm{bc}$ & $0.40 \mathrm{~b}$ & $10.00 \mathrm{c}$ \\
\hline Mean of Pc & $148.9 \mathrm{~A}^{6}$ & $16.5 \mathrm{~A}$ & $0.65 \mathrm{~B}$ & $1281.6 \mathrm{~A}$ & $2.31 \mathrm{~A}$ & $0.32 \mathrm{~B}$ & $9.69 \mathrm{~A}$ \\
\hline \multicolumn{8}{|c|}{ P. vulgaris $(\mathrm{Pv})$} \\
\hline Bart & $81.7 \mathrm{j}$ & $10.6 \mathrm{i}$ & $5.12 \mathrm{~d}$ & $874.2 \mathrm{f}$ & $1.86 \mathrm{~g}$ & $0.30 \mathrm{~d}$ & $7.41 \mathrm{~g}$ \\
\hline SDA & $94.7 \mathrm{i}$ & $13.7 \mathrm{e}$ & $8.25 b$ & 903.6 ef & $2.31 \mathrm{~cd}$ & $0.50 \mathrm{a}$ & 8.44 def \\
\hline SIA & $94.4 \mathrm{i}$ & $13.2 \mathrm{ef}$ & $3.72 \mathrm{e}$ & 905.2 ef & $1.81 \mathrm{~g}$ & $0.30 \mathrm{~d}$ & $6.00 \mathrm{~h}$ \\
\hline SJP & $100.7 \mathrm{~h}$ & $11.0 \mathrm{i}$ & $6.47 c$ & $926.1 \mathrm{e}$ & $2.02 \mathrm{f}$ & $0.40 \mathrm{~b}$ & $8.28 \mathrm{f}$ \\
\hline SS-01 & $109.3 \mathrm{~g}$ & $13.1 \mathrm{ef}$ & $5.77 \mathrm{~cd}$ & $922.9 \mathrm{e}$ & $2.32 \mathrm{~cd}$ & $0.40 \mathrm{~b}$ & $8.98 \mathrm{de}$ \\
\hline SS-02 & $123.3 \mathrm{f}$ & $12.5 \mathrm{gh}$ & $9.65 \mathrm{a}$ & $1132.0 \mathrm{~d}$ & $2.28 \mathrm{~d}$ & $0.37 \mathrm{bc}$ & 8.74 def \\
\hline Mean of Pv & $100.7 \mathrm{~B}$ & $12.4 \mathrm{~B}$ & $6.30 \mathrm{~A}$ & $944.0 \mathrm{~B}$ & $2.10 \mathrm{~B}$ & $0.37 \mathrm{~A}$ & 7.98 B \\
\hline
\end{tabular}

For the flavonoid content, four P. coccineus accessions stood out with values of $20.2-26.3 \mathrm{mg} \mathrm{CE} \mathrm{g}^{-1} \mathrm{dw}$ in the seed coat and from 0.30 to $0.40 \mathrm{mg} \mathrm{CE} \mathrm{g}^{-1} \mathrm{dw}$ in the cotyledons, which differed from all P. vulgaris accessions, as they showed variation between accessions of $10.6-13.7$ and $0.30-0.50 \mathrm{mg} \mathrm{CE} \mathrm{g}^{-1} \mathrm{dw}$ of flavonoids in the seed coat and cotyledons, respectively. This outcome indicates that the variability between P. coccineus accessions is greater than that between P. vulgaris accessions and that there is greater homogeneity in the latter (Table 3).

For the seed coat antioxidant activity by DPPH, it was determined that five P. coccineus accessions had the highest values within a range of $1261.0-1789.2 \mu \mathrm{mol} \mathrm{Eq}$. Trolox $\mathrm{g}^{-1} \mathrm{dw}$. In the case of P. vulgaris, only one accession had a value of $1132.0 \mu \mathrm{mol} \mathrm{Eq.} \mathrm{Trolox} \mathrm{g}^{-1} \mathrm{dw}$, while the other accessions showed a variation of 874.2-922.9 $\mu \mathrm{mol}$ Eq. Trolox $\mathrm{g}^{-1} \mathrm{dw}$. This same pattern is repeated for the antioxidant activity in the cotyledons; however, the variation between $P$. coccineus accessions was 7.18-13.52 $\mu \mathrm{mol}$ Eq. Trolox $\mathrm{g}^{-1} \mathrm{dw}$, and that of P. vulgaris was from 6.0 to $8.98 \mu \mathrm{mol} \mathrm{Eq.} \mathrm{Trolox} \mathrm{g}^{-1} \mathrm{dw}$ (Table 3). The results show that the antioxidant activity is significantly higher in the seed coat than that in the cotyledons for both species, and some $P$. coccineus accessions stand out.

In the clustering and discriminant analysis (Figure 1), the differences and similarities between accessions and species in relation to the polyphenols, flavonoids and anthocyanins content and antioxidant activity in the seed coat and cotyledons were statistically and graphically determined. In the cluster analysis, four contrasting groups were determined: Two P. coccineus (G1 and G2) groups, an intermediate group called P. coccineus-vulgaris (G3) because it was composed of two P. coccineus accessions (SL-01 and SL-02, ID-Accessions) and two P. vulgaris accessions (Bart and AIS, ID-Accessions), and a fourth more compact group composed of four P. vulgaris accessions (G4: SDA, SS-02, SJP and SS-01, ID-Accessions) (Figure 1a). These results show that there are differences and similarities between $P$. coccineus and P. vulgaris, not only in the plant, pod, and seed characteristics but also in the grain composition. 


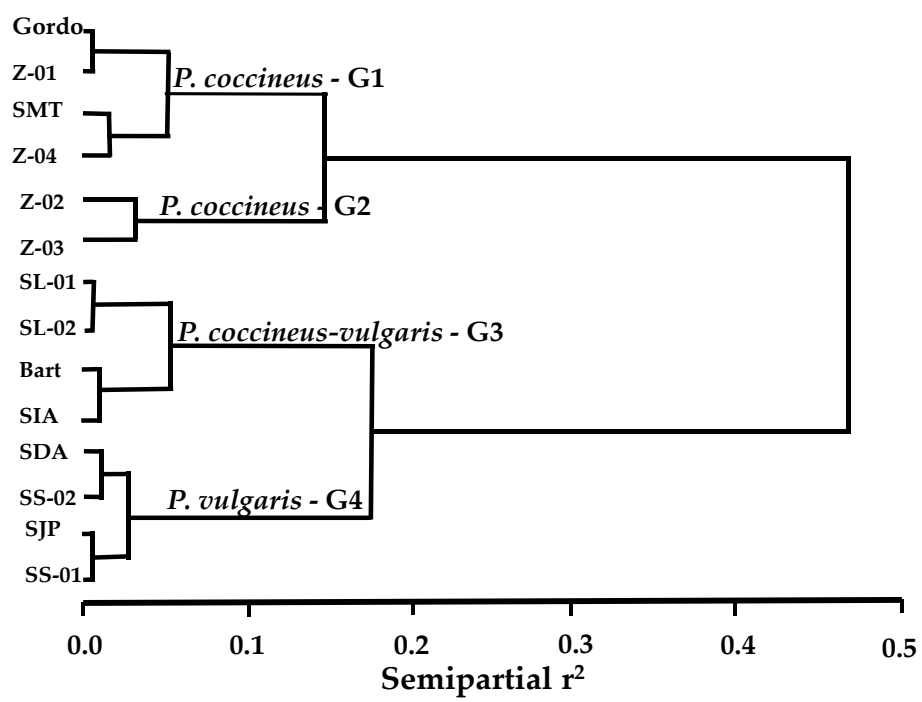

(a)

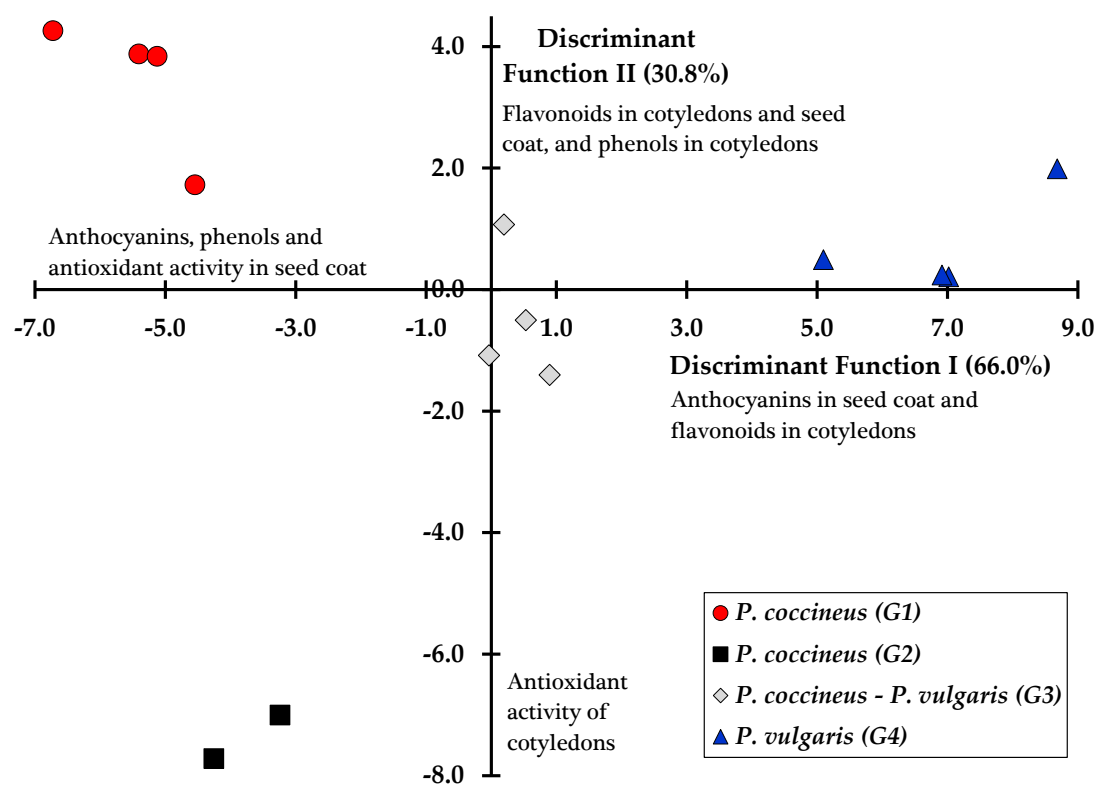

(b)

Figure 1. Hierarchical clustering analysis (a) and scatterplot of accessions from P. coccineus and P. vulgaris in the two first discriminant functions (b) based on the phenolic compounds and antioxidant activity.

The scatter plot of the discriminant analysis presented in Figure $1 \mathrm{~b}$ shows that $P$. coccineus accessions are located predominantly on the left side and P. vulgaris accessions are on the right side. Thus, four P. coccineus accessions (G1), located in the upper left quadrant, differ from the group of $P$. coccineus located in the lower left quadrant (G2); then, there is an intermediate group near the center referred to as the P. coccineus-vulgaris combined group (G3), and finally, four P. vulgaris accessions (upper right) are preferably associated with a higher anthocyanin content in the seed coat and higher flavonoids in the cotyledons. In contrast, P. coccineus showed a lower content of anthocyanins but higher concentrations of phenols and flavonoids, as well as a higher antioxidant activity. 


\section{Discussion}

In the general description of seeds, it was determined that $P$. coccineus accessions had significantly greater seed length, width, thickness, weight, density and volume than those of $P$. vulgaris accessions. The different dimensions, among other factors, are due to characteristics inherent to the species and are influenced by agroecological factors, cultivation practices and places of origin [37-39]. The accessions used in this work came from the cultivation plots of farmers in Oaxaca and one from Veracruz, Mexico, where the P. coccineus variations are highly preferred for the preparation of traditional dishes [40].

The significant differences found between $P$. vulgaris and P. coccineus in grain composition (Tables 2 and 3) suggest that the species have different absorption capacities, translocation and storage of flavonoids, polyphenols and anthocyanins in the cotyledons and seed coat, and these contents are reflected in the antioxidant activity. These interspecies differences were also documented by Onylagha and Islam [41] in regard to the specific contents of flavonoids in the stem and leaves, as well as anthocyanins in the seeds and leaves. In P. coccineus, luteolin and epigenin were determined in the stem and leaves, while in P. vulgaris, kaempferol and quercetin were identified. In the case of anthocyanins in seeds, delphinidin and cyanidin were identified in P. vulgaris, and only cyanidin was identified in P. coccineus. The differences between P. vulgaris and P. coccineus documented by Onylagha and Islam [41] for flavonoids in the stem can explain part of the differences found in our study in respect to the major content of catechins (flavonoids, $\mathrm{mg} \mathrm{CE} \mathrm{g}^{-1}$ ) and gallic acid (polyphenols, $\mathrm{mg} \mathrm{GAE} \mathrm{g}^{-1}$ ) in the seed coat of $P$. coccineus relative to $P$. vulgaris. The differences found reinforce the theory that there is an ability to make different nutritional and nutraceutical contributions that are complementary to health through the consumption of P. vulgaris and P. coccineus because different bioactive compounds are concentrated in the grain.

In both $P$. vulgaris and $P$. coccineus, there was a greater accumulation or concentrations of polyphenols, flavonoids and anthocyanins in the seed coat than in the cotyledons, and, specifically, the amount of anthocyanins in the cotyledons were below the estimated levels. This pattern was also reflected by the greater antioxidant activity in the seed coat than that in the cotyledons (Table 3). Quiroz-Sodi et al. [11] determined a similar trend of a higher polyphenol content in the seed coat than that in the cotyledons for P. coccineus and P. vulgaris. These trends indicate that the largest amount of bioactive compounds accumulate in the seed coat (e.g., anthocyanins) and not in the cotyledons; in the latter structure, the carbohydrates and protein are accumulated instead [42].

Yoshida et al. [14] and Macz-Pop et al. [15] have documented that different anthocyanins are concentrated in P. coccineus grains, and they differ from those found in P. vulgaris. Though specific anthocyanins were not tested in this study, it was determined that $P$. vulgaris presents a higher content of anthocyanins in the seed coat than that in P. coccineus, a pattern that is repeated with the flavonoid content in the cotyledons. The results are opposite in regard to the polyphenol content and antioxidant activity in the seed coat and grain, as well as the flavonoid content being higher in the seed coat of $P$. coccineus (Table 3 ). This suggests that $P$. coccineus and P. vulgaris should be considered complementary foods, and in the rural communities of Mexico and Central America, they are complemented with the consumption of flowers [28].

Regarding the intraspecific variation of phenolic compounds and antioxidant activity, the results showed high variation in P. coccineus and lower variations in P. vulgaris. In this case, all P. vulgaris accessions visually showed a black seed coat, unlike $P$. coccineus accessions that varied in color from dark-gray to brown and black (Table 1). In the latter case, P. coccineus accessions with dark gray, brown, and red seed coats showed a higher phenol content in the seed coat than that in black P. vulgaris accessions with the exception of one (SS-02), as seen in Table 3. The same trend was also tested in P. vulgaris by Ombra et al. [43] in different traditional varieties from Italy. This finding was reversed for the anthocyanin content in the seed coat; the accessions with higher contents were P. vulgaris compared to those of P. coccineus, and this indicates that anthocyanins are determinants of the black color in the seed coat. 
The SMT, Z-03 and Z-04 accessions of P. coccineus stood out for their phenols, flavonoids and antioxidant activity in the seed coat and grain, and in the case of P. vulgaris, SS-02 was the best (Table 3). This indicates that within each species, there are accessions that can be used directly to improve the communities' nutrition or implement a program of genetic improvement towards greater nutritional quality of stand-out grains. That is, few genetic improvement programs of Phaseolus have used grain composition as a selection criterion, and the accessions studied here for both P. coccineus and P. vulgaris are a starting point for a plant breeding program. However, it is necessary to complement them with studies of the amino acid content and other bioactive compounds (e.g., tannins).

The four phenotypic groups classified by the cluster analysis indicate that four P. vulgaris accessions were homogeneous, having similarity in their composition, with an intermediate group of P. coccineus-vulgaris, and two groups of $P$. coccineus (Figure 1a). The results show a greater dispersion or variability in the phenolic compounds and antioxidant activity between $P$. coccineus accessions than that between $P$. vulgaris accessions, a fact that is confirmed in the scatter plot of the discriminant analysis (Figure 1b), where two distant groups of P. coccineus, independent of the P. vulgaris accession group, are noted. The diversity evaluated of $P$. coccineus and $P$. vulgaris with respect to seed composition reflects part of the genetic diversity present in Mesoamerica that was evaluated by Sicard et al. [44].

\section{Conclusions}

Based on the community of origin of the accessions and plant material evaluated to determine the phenolic compounds and antioxidant activity, it was concluded that $P$. coccineus and P. vulgaris significantly differ in their contents of polyphenols, flavonoids, and anthocyanins, as well as their antioxidant activity in the seed coat and cotyledons. However, both species had greater concentrations in the seed coat than in the cotyledons. P. vulgaris had a higher anthocyanin content in the seed coat and a higher content of flavonoids in the cotyledons than that in P. coccineus, but it did not have such for the other compounds evaluated. There was high variability between the accessions evaluated, and, specifically, P. vulgaris accessions had slightly more than double the anthocyanins compared to those of $P$. coccineus. The variability measured between accessions was classified into four phenotypic groups: Two of $P$. coccineus, one P. coccineus-vulgaris combined group, and one group of $P$. vulgaris with greater homogeneity in phenolic compounds and antioxidant activity. Both species are a source of complementary polyphenols, flavonoids and anthocyanins that can be used to improve the diet in rural communities where there is greater access to P. vulgaris and P. coccineus. Other studies are necessary to determine their potential in preventing some chronic degenerative diseases. Likewise, it is important to promote the cultivation of $P$. vulgaris and $P$. coccineus native species in their place of origin, enhancing them in situ and using them as a cheaper source of food.

Author Contributions: A.C.-C., E.N.A.-B. and Y.D.G.-D. contributed to laboratory analysis; E.N.A.-B., J.L.C.-S., A.M.V.-G. and J.C.C.-R. performed the research, data analysis, and they wrote the paper.

Funding: This research was funded by CONACYT-Mexico grant number PN2015-1-1119.

Acknowledgments: The authors are grateful for the financial support provided by CONACYT-Problemas Nacionales (project no. PN2015-1-1119) and the Instituto Politecnico Nacional (project nos. 1922 and 20196672).

Conflicts of Interest: The authors declare no conflict of interest.

\section{References}

1. Delgado-Salinas, A.; Bibler, R.; Lavin, M. Phylogeny of the genus Phaseolus (Leguminosae): A recent diversification in an ancient landscape. Syst. Bot. 2006, 31, 779-791. [CrossRef]

2. Freytag, G.F.; Debouck, D.G. Taxonomy, Distribution, and Ecology of the Genus Phaseolus (Leguminosae-Papilionodeae) in North America, Mexico and Central America; Botanical Miscellany No. 23, SIDA; Botanical Research Institute of Texas: Forth Worth, TX, USA, 2002; p. 298. 
3. Maréchal, R. Etude taxonomique d'un groupe complexe d'espèces des genres Phaseolus et Vigna (Papilionaceae) sur la base de données morphologiques et polliniques, traitées par l'analyse informatique. Boissiera 1978, 28, $1-273$.

4. Boege, E. El patrimonio biocultural de los pueblos indígenas de Mexico. In Hacia la Conservación in situ de la Biodiversidad y Agrobiodiversidad en los Territorios Indígenas; Instituto Nacional de Antropología e Historia y Comisión Nacional para el Desarrollo de los Pueblos Indígenas: Ciudad de Mexico, Mexico, 2010; p. 341.

5. Chávez-Servia, J.L.; Heredia-García, E.; Mayek-Pérez, N.; Aquino-Bolaños, E.N.; Hernández-Delgado, S.; Carrillo-Rodríguez, J.C.; Gill-Langarica, H.R.; Vera-Guzmán, A.M. Diversity of common bean (Phaseolus vulgaris L.) landraces and the nutritional value of their grains. In Grain Legumes; Goyal, A.K., Ed.; InTech: Rijeka, Croatia, 2016; pp. 1-33.

6. Lin, L.-Z.; Harnly, J.M.; Pastor-Corrales, M.S.; Luthria, D.L. The polyphenolic profiles of common bean (Phaseolus vulgaris L.). Food Chem. 2008, 107, 399-410. [CrossRef] [PubMed]

7. Oomah, B.D.; Cardador-Martínez, A.; Loarca-Piña, G. Phenolics and antioxidative activities in common beans (Phaseolus vulgaris L.). J. Sci. Food Agric. 2005, 85, 935-942. [CrossRef]

8. Gálvez-Ranilla, L.; Genovese, M.I.; Lajolo, F.M. Polyphenols and antioxidant capacity of seed coat and cotyledon from Brazilian and Peruvian bean cultivars (Phaseolus vulgaris L.). J. Agric. Food Chem. 2007, 55, 90-98. [CrossRef] [PubMed]

9. Kan, L.; Nie, S.; Hu, J.; Liu, Z.; Xie, M. Antioxidant activities and anthocyanins composition of seed coats from twenty-six kidney bean cultivars. J. Funct. Food 2016, 26, 622-631. [CrossRef]

10. DeMejía,E.G.; Guzmán-Maldonado,S.H.; Acosta-Gallegos, J.A.; Reynoso-Camacho, R.; Ramírez-Rodríguez, E.; Pons-Hernández, J.L.; González-Chavira, M.M.; Castellanos, J.Z.; Kelly, J.D. Effect of cultivar and growing locations on the trypsin inhibitors, tannins, and lectins on common beans (Phaseolus vulgaris L.) grown in the semiarid highlands of Mexico. J. Agric. Food Chem. 2003, 51, 5962-5966. [CrossRef]

11. Quiroz-Sodi, M.; Mendoza-Díaz, S.; Hernández-Sandoval, L.; Carrillo-Ángeles, I. Characterization of the secondary metabolites in the seeds of nine native bean varieties (Phaseolus vulgaris and P. coccineus) from Queretaro, Mexico. Bot. Sci. 2018, 96, 650-661. [CrossRef]

12. Mosisa, M.T. Effect of processing on proximate and mineral composition of black climbing (P. coccineus L.) bean flour. Afr. J. Food Sci. 2017, 11, 74-81.

13. Giupponi, L.; Tamburini, A.; Glorgi, A. Prospect for broader cultivation and commercialization of copafam, a local variety of Phaseolus coccineus L., in the Brescia Pre-Alps. Mt. Res. Dev. 2018, 38, 24-34. [CrossRef]

14. Yoshida, K.; Sato, Y.; Okuno, R.; Kameda, K.; Isobe, M.; Kondo, T. Structural analysis and measurement of anthocyanins from colored seed coats of Vigna, Phaseolus, and Glycine legumes. Biosci. Biotech. Biochem. 1996, 60, 589-593. [CrossRef]

15. Macz-Pop, G.; González-Paramás, A.M.; Pérez-Alonso, J.J.; Rivas-Gonzalo, J.C. New flavonol-anthocyanin condensed pigments and anthocyanins composition in Guatemalan beans (Phaseolus spp.). J. Agric. Food Chem. 2006, 54, 536-542. [CrossRef] [PubMed]

16. Soleri, D.; Worthington, M.; Aragón-Cuevas, F.; Smith, S.E.; Gepts, P. Farmers' varietal identification in a reference sample of local Phaseolus species in the Sierra Juárez, Oaxaca, Mexico. Econ. Bot. 2013, 67, 283-298. [CrossRef]

17. Vargas-Vázquez, M.L.; Muruaga-Martínez, J.S.; Mayek-Pérez, N.; Pérez-Guerrero, A.; Ramírez-Sánchez, S.E. Characterization of the runner bean (Phaseolus coccineus L.) of the trans-Mexican Neovolcanic belt and Sierra Madre oriental. Rev. Mex. Cienc. Agric. 2014, 5, 191-200.

18. Chávez-Servia, J.L.; Carrillo-Rodríguez, J.C.; Vera Guzmán, A.M.; Aquino-Bolaños, E.N.; Hernández-Delgado, S.; Mayek-Pérez, N.; Lobato-Ortiz, R. Traditional family production and nutritional-nutraceutical value of common beans (Phaseolus vulgaris L.) in Southeast Mexico. In Phaseolus vulgaris: Cultivars, Production and Uses; Campos-Vega, R., Bassinello, P.Z., Ooma, B.D., Eds.; Nova Science Publishers Inc.: Hauppauge, NY, USA, 2018; pp. 167-198.

19. Gutiérrez, J.P.; Rivera-Dommarco, J.; Shamah-Levy, T.; Villalpando-Hernández, S.; Franco, A.; Cuevas-Nasu, L.; Romero-Martínez, M.; Hernández-Ávila, M. Encuesta Nacional de Salud y Nutrición 2012. In Resultados Nacionales; Instituto Nacional de Salud Pública: Cuernavaca, Mexico, 2012; p. 196.

20. Aguirre-Arenas, J.; Escobar-Pérez, M.; Chávez-Villasana, A. Evaluation of the food consumption and nutrition in four rural communities. Salud Publica en Mexico 1998, 40, 398-407. 
21. Bazzano, L.A.; He, J.; Ogden, L.G.; Loria, C.; Vupputuri, S.; Myers, L.; Whelton, P.K. Legume consumption and risk of coronary heart disease in US men and woman. Arch. Intern. Med. 2001, 161, 2573-2578. [CrossRef] [PubMed]

22. Bourdon, I.; Olson, B.; Backus, R.; Richter, B.D.; Davis, P.A.; Schneeman, B.O. Beans as a source of dietary fiber increase cholecystokinin and apolipoprotein b48 response to test meals in men. J. Nutr. 2001, 131, 1485-1490. [CrossRef]

23. Beninger, C.W.; Hosfield, G.L. Antioxidant activity of extracts, condensed tannin fractions, and pure flavonoids from Phaseolus vulgaris L. seed coat color genotypes. J. Agric. Food Chem. 2003, 51, 7879-7883. [CrossRef]

24. Choung, M.G.; Choi, B.R.; An, Y.N.; Chu, Y.H.; Cho, Y.S. Anthocyanin profile of Korean cultivated kidney bean (Phaseolus vulgaris L). J. Agric. Food Chem. 2003, 51, 7040-7043. [CrossRef]

25. Lazze, M.C.; Pizzala, R.; Savio, M.; Stivala, L.A.; Prosperi, E.; Bianchi, L. Anthocyanins protect against DNA damage induced by tert-butylhydroperoxide in rat smooth muscle and hepatoma cells. Mutat. Res. Genet. Toxicol. Environ. Mutagen. 2003, 535, 103-115. [CrossRef]

26. Huber, K.; Brigide, P.; Bretas, E.B.; Canniatti-Brazaca, S.G. Phenolic acid, flavonoids and antioxidant activity of common brown beans (Phaseolus vulgaris L.) before and after cooking. J. Nutr. Food Sci. 2016, 6, 5. [CrossRef]

27. Labuda, H. Runner bean (Phaseolus coccineus L.)-Biology and use. Acta Sci. Pol. Hortorum Cultus 2010, 9, 117-132.

28. Ayala-Garay, O.J.; Pichardo-González, J.M.; Estrada-Gómez, J.A.; Carrillo-Salazar, J.A.; Hernández-Livera, A. Yield and seed quality of Ayocote bean at the Valley of Mexico. Agric. Tecn. Mex. 2006, 32, 313-321.

29. Aquino-Bolaños, E.N.; García-Díaz, Y.D.; Chavez-Servia, J.L.; Carrillo-Rodríguez, J.C.; Vera-Guzmán, A.M.; Heredia-García, E. Anthocyanins, polyphenols, flavonoids and antioxidant activity in common bean (Phaseolus vulgaris L.) landraces. Emir. J. Food Agric. 2016, 28, 581-588. [CrossRef]

30. Singleton, V.L.; Rossi, J.A. Colorimetry of total phenolics with phosphomolybdic phosphotungstic acid reagents. Am. J. Enol. Vitic. 1965, 16, 144-158.

31. Zhishen, J.; Mengcheng, T.; Jianming, W. The determination of flavonoids contents in mulberry and their scavenging effects in superoxide radicals. Food Chem. 1999, 64, 555-559. [CrossRef]

32. Giusti, M.M.; Wrolstad, R.E. Characterization and measurement of anthocyanins by UV-visible spectroscopy. Curr. Protoc. Food Anal. Chem. 2001, 2, F1.2.1-CF1.2.13. [CrossRef]

33. Brand-Williams, W.; Cuvelier, M.E.; Berset, C. Use of free radical method to evaluate antioxidant activity. LWT-Food Sci. Technol. 1995, 28, 25-30. [CrossRef]

34. Statistical Analysis System (SAS). SAS/STAT User's Guides; Release 9.0; SAS Institute Inc.: Cary, NC, USA, 2002; p. 4424.

35. Bitocchi, E.; Nanni, L.; Bellucci, E.; Rossi, M.; Giardini, A.; Zeuli, P.S.; Logozzo, G.; Stougaard, J.; McClean, P.; Attene, G.; et al. Mesoamerican origin of the common beans (Phaseolus vulgaris L.) is revealed by sequence data. Proc. Natl. Acad. Sci. USA 2012, 109, E788-E796. [CrossRef]

36. Guerra-García, A.; Suárez-Atilano, M.; Mastretta-Yanez, A.; Delgado-Salinas, A.; Piñeiro, D. Domestication genomics of the open-pollinated scarlet runner bean (Phaseolus coccineus L.). Front. Plant Sci. 2017, 8, 1891. [CrossRef]

37. Zeven, A.C.; Mohamed, H.H.; Waninge, J.; Veurink, H. Phenotypic variation within landrace of runner bean (Phaseolus coccineus L.). Euphytica 1993, 68, 155-166. [CrossRef]

38. Vargas-Vázquez, M.L.; Muruaga-Martínez, J.S.; Pérez-Herrera, P.; Gil-Langarica, H.R.; Esquivel-Esquivel, G.; Martínez-Damian, M.A.; Rosales-Serna, R.; Mayek-Pérez, N. Morphoagronomic characterization of the INIFAP core collection of the cultivated form of common bean. Agrociencia 2008, 42, 787-797.

39. Sinkovič, L.; Pipan, B.; Sinkovič, E.; Meglic, V. Morphological seed characterization of common (Phaseolus vulgaris L.) and runner (Phaseolus coccineus L.) bean germplasm: A Slovenian gene bank example. BioMed Res. Intern. 2019, 2019, 6376948. [CrossRef] [PubMed]

40. Palmero, D.; Iglesias, C.; de Cara, M.; Tello, J.C.; Camacho, F. Diversity and health traits of local landraces of runner bean (Phaseolus coccineus L.) from Spain. J. Food Agric. Environ. 2011, 9, 290-295.

41. Onylagha, J.C.; Islam, S. Flavonoids and other polyphenols of the cultivated species of the genus Phaseolus. Int. J. Agric. Biol. 2009, 11, 231-234. 
42. Chávez-Mendoza, C.; Hernández-Figueroa, K.; Sánchez, E. Antioxidant capacity and phytonutrient content in the seed coat and cotyledon of common beans (Phaseolus vulgaris L.) from various regions in Mexico. Antioxidants 2019, 8, 1-19.

43. Ombra, M.N.; d'Acierno, A.; Nazzaro, F.; Riccardi, R.; Spigno, P.; Zaccardelli, M.; Pane, C.; Maione, M.; Fratianni, F. Phenolic composition and antioxidant and antiproliferative activities of the extracts of twelve common bean (Phaseolus vulgaris L.) endemic ecotypes of Southern Italy before and after cooking. Oxid. Med. Cell. Long. 2016, 2016, 1398298. [CrossRef]

44. Sicard, D.; Nanni, L.; Porfiri, O.; Bulfon, D.; Papa, R. Genetic diversity of Phaseolus vulgaris L. and P. coccineus L. landraces in central Italy. Plant Breed. 2005, 124, 464-472. [CrossRef]

(C) 2019 by the authors. Licensee MDPI, Basel, Switzerland. This article is an open access article distributed under the terms and conditions of the Creative Commons Attribution (CC BY) license (http://creativecommons.org/licenses/by/4.0/). 